\title{
The Content of Copper and Heavy Metals in the Multilayer Soil Mud from the Buchim Lake Under the Buchim Mine's Waste Dump, Republic North Macedonia
}

TODOR S. SERAFIMOVSKI, University „Goce Delcev“, Original scientific paper Faculty of natural and technical sciences, Štip, R. N. Macedonia UDC: 504.5:669.3(497.7) GORAN K. TASEV, University „Goce Delcev“, DOI: 10.5937/tehnika2003297S

Faculty of natural and technical sciences, Štip, R. N. Macedonia

TRAJCE Z. STAFILOV, University „Ss Cyril and Methodius“,

Faculty of Natural Sciences and Mathematics,

Institute of Chemistry, Skopje, R. N. Macedonia

\begin{abstract}
The intense mineral extraction in mining areas during the last several decades has produced a large amount of waste material and tailings, which release toxic elements to the environment. The aim of the study was to determine in two vertical profiles/sections (1 and 2) the heavy metal contents of samples derived from six samples, three from each section located in the porphyry copper mine Buchim area, Republic North Macedonia. The results have been compared to new Dutchlist (DL) and Kabata-Pendias (KP) standards and the following was concluded: As values ranged 14.985 $\div 60.131 \mathrm{mg} \mathrm{kg}^{-1}$ with 4 samples above the target value of the DL (29 $\left.\mathrm{mg} \mathrm{kg}^{-1} \mathrm{As}\right)$ and 6 above standard values given in $\mathrm{KP}$ value $\left(5 \mathrm{mg} \mathrm{kg}^{-1} \mathrm{As}\right)$, in that context Co values ranged $11 \div 57 \mathrm{mg} \mathrm{kg}^{-1}$ with 6 values above the target value of the DL (9 mg kg-1 Co) and 5 above standard values given in $\mathrm{KP}$ value $\left(12 \mathrm{mg} \mathrm{kg}^{-1} \mathrm{Co}\right)$, Cr with range $29.32 \div 75.76 \mathrm{mg} \mathrm{kg}^{-1}$ with 6 over KP value $\left(10 \mathrm{mg} \mathrm{kg}^{-1} \mathrm{Cr}\right)$ and none above the target value of the $\mathrm{DL}\left(100 \mathrm{mg} \mathrm{kg}^{-1} \mathrm{Cr}\right)$, Cu with range $2694 \div 6749 \mathrm{mg}$ $\mathrm{kg}^{-1}$ with 6 samples above the target value of the $\mathrm{DL}\left(36 \mathrm{mg} \mathrm{kg}^{-1} \mathrm{Cu}\right)$ and 6 above standard values given in $K P$ value $\left(20 \mathrm{mg} \mathrm{kg}^{-1} \mathrm{Cu}\right)$, Ni with range $59.57 \div 105.98 \mathrm{mg} \mathrm{kg}^{-1}$ with 6 samples above the target value of the $D L\left(35 \mathrm{mg} \mathrm{kg}^{-1} \mathrm{Ni}\right)$ and 6 above standard values given in $\mathrm{KP}$ value $\left(20 \mathrm{mg} \mathrm{kg}^{-1} \mathrm{Ni}\right), \mathrm{Pb}$ with range 27.06 $\div 96.08 \mathrm{mg} \mathrm{kg}^{-1}$ with 1 sample above the target value of the $\mathrm{DL}\left(85 \mathrm{mg} \mathrm{kg}^{-1} \mathrm{~Pb}\right)$ and 6 above standard values given in $\mathrm{KP}$ value $\left(25 \mathrm{mg} \mathrm{kg}^{-1} \mathrm{~Pb}\right)$, Zn with range $147 \div 273 \mathrm{mg} \mathrm{kg}^{-1}$ with 6 over target value of the DL $(140 \mathrm{mg}$ $\left.\mathrm{kg}^{-1} \mathrm{Zn}\right)$ and 6 above standard $\mathrm{KP}$ value $\left(64 \mathrm{mg} \mathrm{kg}^{-1} \mathrm{Zn}\right)$, V with range $34.44 \div 92.57 \mathrm{mg} \mathrm{kg}^{-1}$ with 5 over target value of the $D L\left(42 \mathrm{mg} \mathrm{kg}^{-1} \mathrm{~V}\right)$ and one above KP value $\left(90 \mathrm{mg} \mathrm{kg}^{-1} \mathrm{~V}\right)$.In order to compare the level of contamination, the contamination factor $\left(C_{f}^{i}\right)$, degree of contamination $\left(C_{d}\right)$, and pollution load index $(P L I)$ were computed. Serious numbers were found for $\mathrm{Cu}, \mathrm{As}, \mathrm{Zn}$, Co and $\mathrm{Ni}$, which exceeded standard values at almost all samples from both vertical sections. Compared from section 1 and section 2, pollution load index increased by $13.43 \%$, which in almost all samples was classified as heavily polluted to extremely polluted. The fact that mining activities at the Buchim Mine last for almost 40 years, the presence of heavy metals in soils at a serious level is understandable. The high level of contamination is a result of heavy metal persistence and non-biodegradability.
\end{abstract}

Key words: soil, pollution, copper, porphyry, Buchim

\section{INTRODUCTION}

A very serious environmental problem around the World poses toxicity and persistence of heavy metals

Author's address: Todor Serafimovski, University „Goce Delčev“ Faculty of Natural and Technical Sciences, Štip, Bulevar Krste Misirkov 10a, R. N. Macedonia

e-mail: todor.serafimovski@ugd.edu.mk

Paper received: 16.03.2020.

Paper accepted: 26.05.2020. which are accumulated in the environment as the result of diverse industrial activities. As it is already well known there are many different sources of heavy metal contaminants, including mining and metallurgical industries [1].

With the rapid development of mining activities landscape changes as well as environmental pollution have become still more serious. Particular emphasis is given on ore deposits, mining, processing and flotation plants as significant anthropogenic sources of dust [2], 
[3], [4], [5]. Copper mines with open ore pit type, where the intense mineral extraction has produced a large amount of waste material accumulated on the heaps or tailings [6], represent potentially emission source of heavy metals in the air, soil and water. Also, other pollution contributing processes are: minerals blasting, drilling and crushing, their loading and transportation to processing and flotation plants. Without proper management, mines and tailings are the source of heavy metals, which are washed out by precipitation and can contaminate all environmental components [7]. The extent and degree of heavy metal contamination vary depending upon the mineralogical and geochemical characteristics of both ore and host rocks [8]. We would like to stress out that soil is a critical environment because it is able to accumulate pollutants produced by anthropogenic activities, such as mining and processing of ore, industry, agriculture, traffic, etc. The transport of heavy metals in soil is the result of processes between soil and metal components, which include processes of physical, chemical, and biological nature [9]. However, soil is not only a passive acceptor of heavy metals, polluted soils become a source of contamination for other environmental components and the food chain [10]. In addition, heavy metals are non-degradable and persistent, their presence in soil is stable and long-term [12]. In the Republic North Macedonia, a lot of attention has been paid to the area of the Buchim Mine which is considered environmentally loaded and unhealthy. There, high levels of heavy metals were found not only in soil, water or sediment samples [11], [12], [13], [14], [15], but several studies detected extremely high levels of heavy metals in plants [16], [17]. The aim of the study was (1) to determine the level of contamination with heavy metals in the area of Buchim Lake just below the Buchim Mine waste dump in two vertical soil sections (1A-C, 2A-C), (2) to compare the level of contamination between the studied sections using the contamination factor, degree of contamination, and pollution load index, (3) to assess the correlation relationship between heavy metals and significant differences in heavy metal pollution between the studied sections.

\section{MATERIALS AND METHODS}

For almost 40 years mining activities in the region of the Buchim Mine were focused on copper and gold ore mining and processing. Moreover, based on the environmental regionalization, the area is considered environmentally loaded and hazardous for human health. Mining activities started here in the 1979 and peaked during the period 2005-2017. During the years, production mine areas, heaps of waste material and tailing ponds significantly increased their volumes and became the source of undesirable substances, heavy metals. From the geographical point of view, the area (ca. $375 \mathrm{~km}^{2}$ ) is situated in the Radovis Valley and Damjan's Field. The population (ca.16000) is concentrated predominantly in the city of Radovis and adjacent villages. Climatologically the region is characterized as moderate Adriatic-continental climate with coldest month January with $1.2^{\circ} \mathrm{C}$ as an average and warmest months July and August with an average tempe ratures of $23^{\circ} \mathrm{C}$. Position of the sampling sites is shown in Figure 1 and Figure 2.

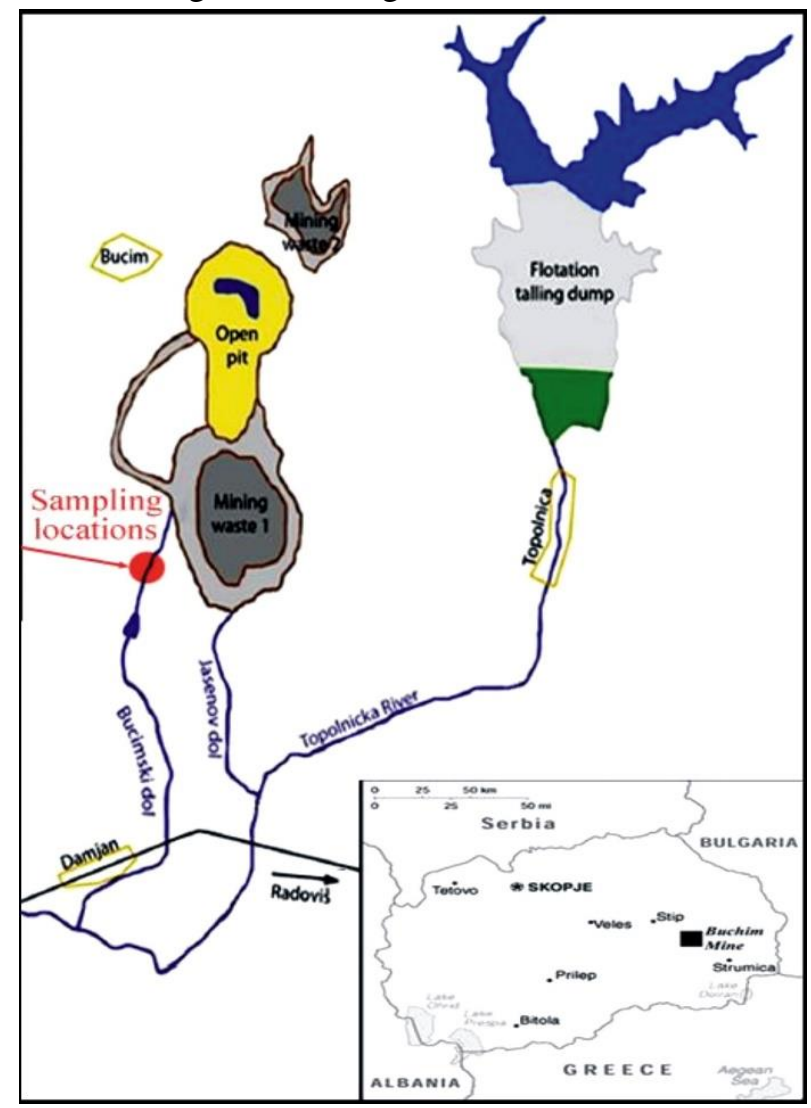

Figure 1 - Position of the Buchim Mine, its facilities and sampling location

The tailing pond, copper processing plant, and a couple heaps of waste material randomly distributed over the study area represent the main sources of toxic elements (Figure 1). The tailing pond is localized in the western part of the Radovis city cadastre in the immediate vicinity of the Topolnica village. Waste material occurring in the upper part of the pond is of powder consistency. The plant located in the Buchim Mine has long been used for copper ore processing. Mud soil sampling from 2 sampling sites in the active mining area of the Buchim Mine was carried out (Fig. 2) from the horizons A, B and C $(5,15,20 / 25 \mathrm{~cm})$, which are usually under water while during summer/autumn season are dry. From each sampling site three samples were collected. Samples were stored in plastic bags, air dried in laboratory conditions, crushed, sieved 
through $2 \mathrm{~mm}$ sieve and grinded in agate mill to obtain particles below $0.1 \mathrm{~mm}$. Then, the samples were digested by applying a mixture of $\mathrm{HNO} 3, \mathrm{HClO} 4, \mathrm{HF}$ and $\mathrm{HCl}$ in accordance with the international standards ISO 14869-1:2001. The obtained solution is filtered through filter paper and quantitatively transferred into a 25 $\mathrm{ml}$ volumetric flask. The flask is supplemented with distilled water. Analysis of the soil samples has determined the content of a total of 20 elements (As, Al, B,

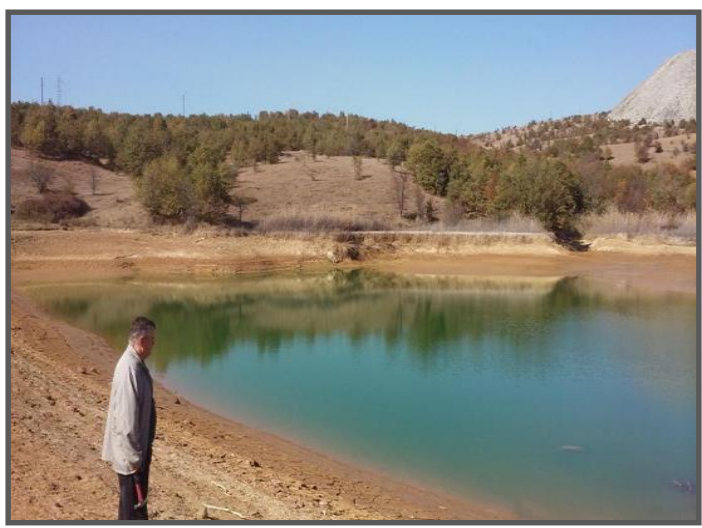

a)

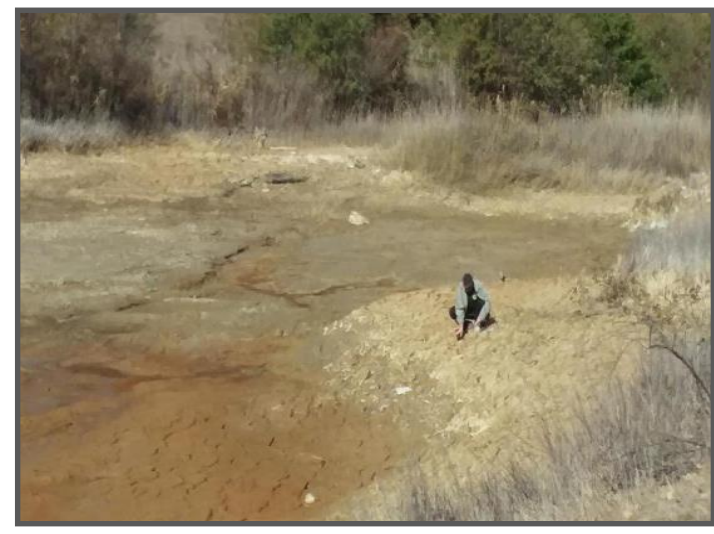

c)
$\mathrm{Ba}, \mathrm{Ca}, \mathrm{Co}, \mathrm{Cr}, \mathrm{Cu}, \mathrm{Fe}, \mathrm{K}, \mathrm{Li}, \mathrm{Mg}, \mathrm{Mn}, \mathrm{Na}, \mathrm{Ni}, \mathrm{P}, \mathrm{Pb}$, $\mathrm{Sr}, \mathrm{V}$ and $\mathrm{Zn}$ ) with application of the atomic emission spectrometer with inductively coupled plasma (ICPAES), model Varian 715-ES. Both soil certified reference material (JSAC 0401) and spiked intra-laboratory samples were analyzed at a combined frequency of $20 \%$ of the samples. Recovery for spiked samples ranged $90-110 \%$, while the recovery for the certified reference material ranges $94-108 \%$.

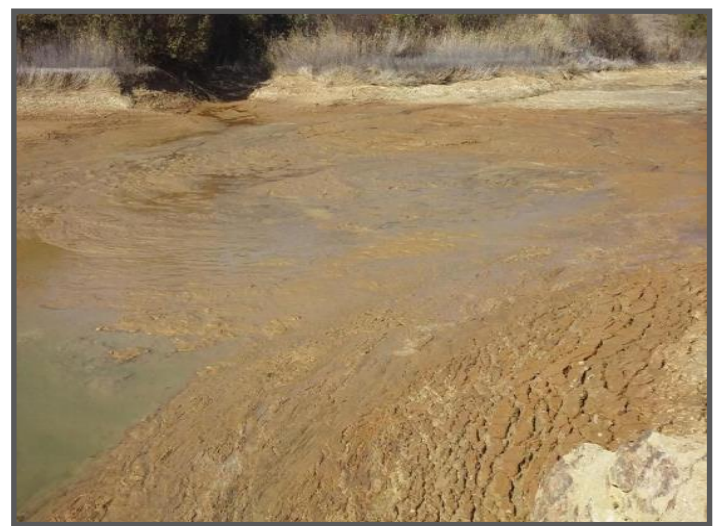

b)

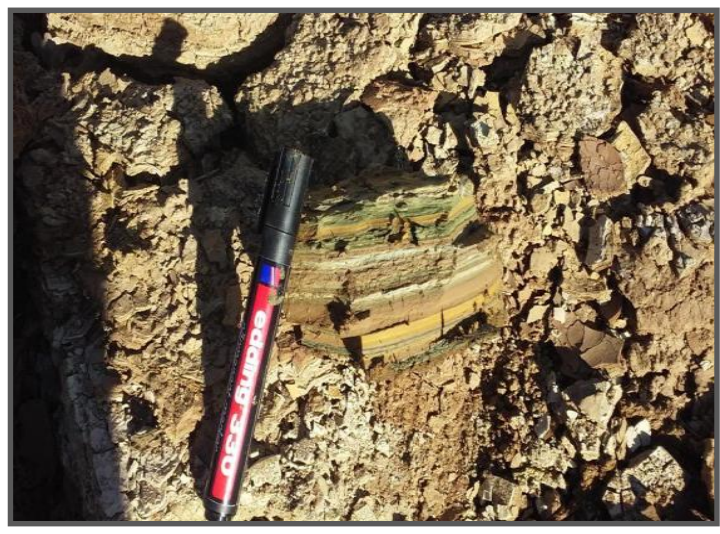

d)

Figure 2 - Bucim Lake and positions of the soil vertical sections sampling locations a) Buchim Lake and the first sampling position; $b$ ) The second sampling position; $c$ ) The process of sampling at the second position; d) a variety of colored vertical layers at the second sampling position

\section{RESULTS AND DISCUSSION}

As we assumed, mining and ore processing in the active Buchim Mine during the period of almost 40 years have left its certain environmental footprint. The latest study and laboratory results of 20 elements (As, $\mathrm{Al}, \mathrm{B}, \mathrm{Ba}, \mathrm{Ca}, \mathrm{Co}, \mathrm{Cr}, \mathrm{Cu}, \mathrm{Fe}, \mathrm{K}, \mathrm{Li}, \mathrm{Mg}, \mathrm{Mn}, \mathrm{Na}, \mathrm{Ni}$, $\mathrm{P}, \mathrm{Pb}, \mathrm{Sr}, \mathrm{V}$ and $\mathrm{Zn}$ ), confirmed their increased contents, sometimes even of several magnitudes higher than allowed or standard values, especially for the heavy metals such are $\mathrm{As}, \mathrm{Co}, \mathrm{Cr}, \mathrm{Cu}, \mathrm{Ni}, \mathrm{Pb}, \mathrm{V}$ and Zn (Table 1).

Since we were exactly interested on heavy metals pollution, ours further efforts were diverted in direction of analyzing and discussing heavy metals and their statistical "behavior" in the sampled soil horizons around the Buchim Mine. The most intriguing results have been found, in regards to the new Dutchlist [18] and other standard values [19], for arsenic, cobalt, chromium, copper, nickel, lead, zinc and vanadium. Namely, arsenic showed values in the range $14.985 \div 60.131 \mathrm{mg} \mathrm{kg}-1$ As averaging $36.41 \mathrm{mg} \mathrm{kg}-1$ As, which pointed to values up to $2 \div 12$ times higher than standard values. Cobalt values were in the range $11 \div 57 \mathrm{mg} \mathrm{kg}-1 \mathrm{Co}$, averaging $33.70 \mathrm{mg} \mathrm{kg}-1 \mathrm{Co}$, which pointed to values up to $1.5 \div 5$ times higher than standard values. Chromium showed values within range $29.32 \div 75.76 \mathrm{mg} \mathrm{kg}-1 \mathrm{Cr}$, averaging $61.75 \mathrm{mg} \mathrm{kg}-^{1} \mathrm{Cr}$, 
which according to [20] were not above the standard values while according to [21] were $3 \div 7$ times higher than standard values.

Copper values were within the range $2694 \div 6749$ mg kg-1 $\mathrm{Cu}$, averaging $4189.92 \mathrm{mg} \mathrm{kg}^{-1} \mathrm{Cu}$ that is
$74 \div 337$ times higher than respective standard values. Nickel values within range $59.57 \div 105.98 \mathrm{mg} \mathrm{kg}^{-1} \mathrm{Ni}$, averaging $78.89 \mathrm{mg} \mathrm{kg}^{-1} \mathrm{Ni}$ showed nickel presence in general is $2 \div 5$ times higher than respective standard values.

Table 1. Analysis results of soil mud samples from the vicinity of the Buchim Mine (Buchim Lake), Republic North Macedonia (all the results are in $\mathrm{mg} \mathrm{kg}^{-1}$ )

\begin{tabular}{|l|l|l|l|l|l|l|l|l|l|l|}
\hline Elem. & \multicolumn{1}{|c|}{$1 \mathrm{~A}$} & \multicolumn{1}{|c|}{$1 \mathrm{~B}$} & \multicolumn{1}{|c|}{$1 \mathrm{C}$} & \multicolumn{1}{|c|}{$2 \mathrm{~A}$} & \multicolumn{1}{|c|}{ 2B } & \multicolumn{1}{|c|}{ 2C } & \multicolumn{1}{|c|}{ Min. } & \multicolumn{1}{c|}{ Max. } & \multicolumn{1}{|c|}{ Averag } & \multicolumn{1}{c|}{ Std.dev. } \\
\hline $\mathrm{Al}$ & 29502.52 & 67419.23 & 35724.11 & 19327.10 & 58138.51 & 46242.57 & 19327.10 & 67419.23 & 42725.67 & 18061.36 \\
\hline $\mathrm{As}$ & 14.99 & 35.31 & 34.25 & 21.94 & 51.86 & 60.13 & 14.99 & 60.13 & 36.41 & 17.18 \\
\hline $\mathrm{B}$ & 14.73 & 15.97 & 9.18 & 10.98 & 15.58 & 17.05 & 9.18 & 17.05 & 13.92 & 3.12 \\
\hline $\mathrm{Ba}$ & 76.38 & 52.44 & 57.48 & 35.67 & 49.54 & 125.86 & 35.67 & 125.86 & 66.23 & 32.05 \\
\hline $\mathrm{Ca}$ & 1002.25 & 665.25 & 1695.59 & 1259.98 & 591.64 & 639.48 & 591.64 & 1695.59 & 975.70 & 437.42 \\
\hline $\mathrm{Co}$ & 34.75 & 11.00 & 30.96 & 57.00 & 24.07 & 44.43 & 11.00 & 57.00 & 33.70 & 15.97 \\
\hline $\mathrm{Cr}$ & 74.57 & 61.73 & 60.62 & 29.32 & 68.47 & 75.76 & 29.32 & 75.76 & 61.75 & 17.08 \\
\hline $\mathrm{Cu}$ & 2694.28 & 5833.58 & 3816.52 & 2777.73 & 3268.13 & 6749.27 & 2694.28 & 6749.27 & 4189.92 & 1701.31 \\
\hline $\mathrm{Fe}$ & 33167.42 & 30907.67 & 28019.67 & 14095.58 & 32116.00 & 45223.00 & 14095.58 & 45223.00 & 30588.22 & 10018.68 \\
\hline $\mathrm{K}$ & 7930.27 & 17319.44 & 10920.52 & 2237.11 & 12159.21 & 10792.86 & 2237.11 & 17319.44 & 10226.57 & 4978.97 \\
\hline $\mathrm{Li}$ & 9.53 & 9.66 & 8.20 & 4.47 & 10.50 & 14.14 & 4.47 & 14.14 & 9.42 & 3.15 \\
\hline $\mathrm{Mg}$ & 1384.00 & 418.07 & 638.90 & 2344.96 & 1461.50 & 2138.69 & 418.07 & 2344.96 & 1397.69 & 772.80 \\
\hline $\mathrm{Mn}$ & 1739.22 & 628.10 & 615.34 & 4698.37 & 760.58 & 1428.26 & 615.34 & 4698.37 & 1644.98 & 1565.59 \\
\hline $\mathrm{Na}$ & 608.03 & 2857.57 & 7070.13 & 220.45 & 997.93 & 455.02 & 220.45 & 7070.13 & 2034.86 & 2643.10 \\
\hline $\mathrm{Ni}$ & 59.57 & 61.76 & 105.98 & 83.37 & 67.43 & 95.24 & 59.57 & 105.98 & 78.89 & 19.07 \\
\hline $\mathrm{P}$ & 596.17 & 826.19 & 799.70 & 474.72 & 827.82 & 874.63 & 474.72 & 874.63 & 733.20 & 159.76 \\
\hline $\mathrm{Pb}$ & 71.68 & 83.55 & 37.15 & 27.06 & 45.78 & 96.08 & 27.06 & 96.08 & 60.22 & 27.58 \\
\hline $\mathrm{Sr}$ & 15.51 & 198.44 & 25.28 & 10.99 & 16.41 & 14.42 & 10.99 & 198.44 & 46.84 & 74.42 \\
\hline $\mathrm{V}$ & 88.29 & 67.08 & 75.19 & 34.44 & 81.25 & 92.57 & 34.44 & 92.57 & 73.14 & 21.03 \\
\hline $\mathrm{Zn}$ & 147.48 & 132.15 & 235.57 & 272.53 & 172.35 & 249.94 & 132.15 & 272.53 & 201.67 & 58.53 \\
\hline
\end{tabular}

Lead values were within the range $27.06 \div 96.08$ $\mathrm{mg} \mathrm{kg}^{-1} \mathrm{~Pb}$, averaging $60.22 \mathrm{mg} \mathrm{kg}^{-1} \mathrm{~Pb}$ that is $1.5 \div 4$ times higher than respective standard values. Zinc values were within the range $147 \div 273 \mathrm{mg} \mathrm{kg}^{-1} \mathrm{Zn}$, averaging $201.67 \mathrm{mg} \mathrm{kg}^{-1} \mathrm{Zn}$, which is $1.5 \div 4$ times higher than respective standard values. Vanadium values were within the range $34.44 \div 92.57 \mathrm{mg} \mathrm{kg}^{-1} \mathrm{~V}$, averaging $73.14 \mathrm{mg} \mathrm{kg}^{-1} \mathrm{~V}$ which is $1.5 \div 3$ times higher than respective standard values. For better spatial insight into those findings we plotted measured concentrations of certain heavy metals versus respective standard values, both, [18] and [19] (Fiure 3).

Bivariate statistics has been applied in order to determine the correlation degree between the examined elements, which shows that when the absolute value of the correlation coefficient extends from 0.3 to 0.7 , then, it is a matter of good association of the elements, and when such values extend from 0.7 to 1.0 , then we can say that there is strong connection between the examined elements. Significant correlation factors, were determined for the mineral pairs Co-Zn (0.830), $\mathrm{Cr}-\mathrm{Pb}$ (0.702), Cr-V (0.988), Cu-Pb (0.775) and Ni-Zn
(0.824). All of them reflect natural affinity of aforementioned elements to enter into solid solution with each other.

For determination of metal pollution in soils, contamination factor $\left(C_{f}^{i}\right)$ and degree of contamination $\left(C_{d}\right)$ were used [20], Table 2. The $C_{f}^{i}$ is a singlemetal index determined by the relation:

$$
C_{f}^{i}=\frac{C_{0-1}^{i}}{C_{n}^{i}}
$$

where: $C_{0-1}^{i}-$ concentration of metal in the sample

$C_{n}^{i}$-background level of metal in upper Earth's crust

The background values of metals $\left(C_{n}^{i}\right)$ in natural soils were considered as 29, 9, 100, 36, 35, 85, 42 and140 mg/kg for As, Co, Cr, Cu, Ni, Pb, V and $\mathrm{Zn}$, respectively [18] as well as compared to those of 5,12 , 10, 20, 20, 25, 90 and $64 \mathrm{mg} / \mathrm{kg}$ for $\mathrm{As}, \mathrm{Co}, \mathrm{Cr}, \mathrm{Cu}, \mathrm{Ni}$, $\mathrm{Pb}, \mathrm{V}$ and $\mathrm{Zn}$, respectively [19]. Here in our study we used four classes that were recognized by [20]: 


\begin{tabular}{|l|l|l|l|}
\hline Class & Factor of contamination & $C_{f}^{i}$ & \multicolumn{1}{|c|}{$\mathrm{C}_{\mathrm{d}}$} \\
\hline (i) & low & $<1$ & $<8$ \\
\hline (ii) & moderate & $1-3$ & $8-16$ \\
\hline (iii) & considerable & $3-6$ & $16-32$ \\
\hline (iv) & very high & $\geq 6$ & $\geq 32$ \\
\hline
\end{tabular}

The $C_{d}$ is a measure of the degree of overall

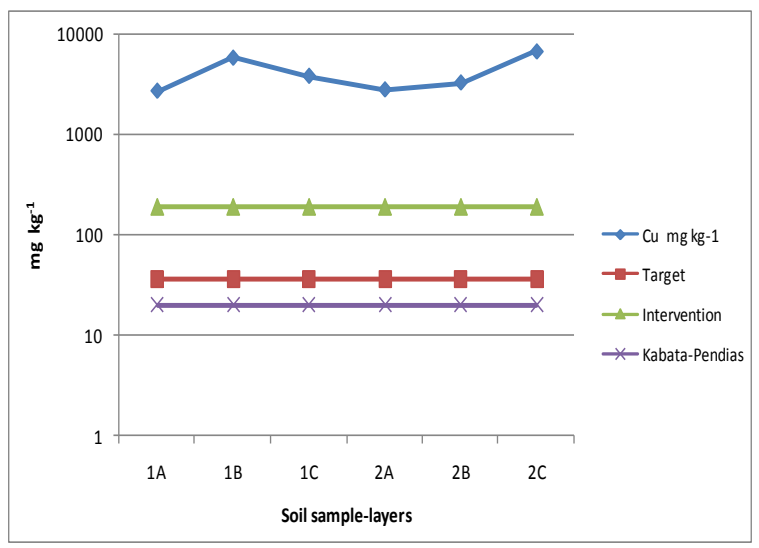

a)

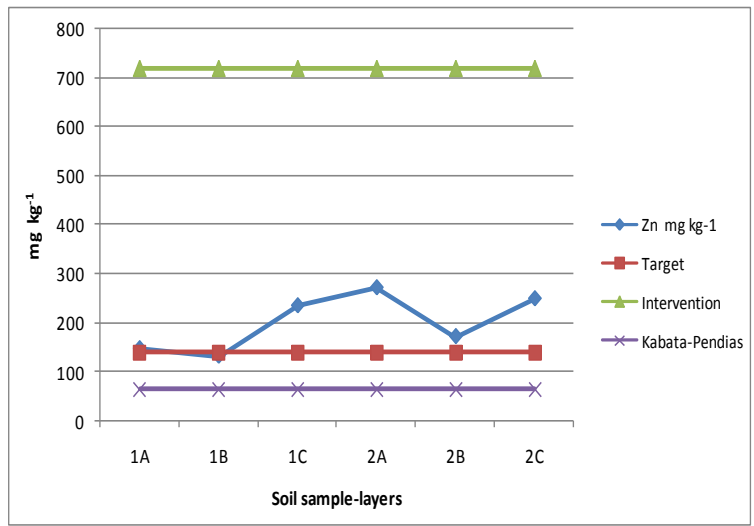

c) contamination in a particular sampling site and was defined as the sum of all $C_{f}^{i}$ :

$$
C_{d}=\sum_{i=0}^{n} C_{f}^{i}
$$

The $C_{d}$, according to [24], was divided into four groups see above.

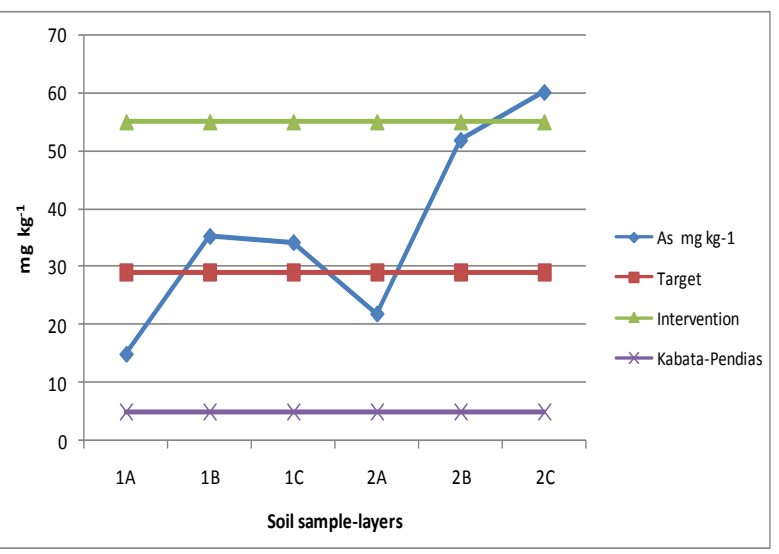

b)

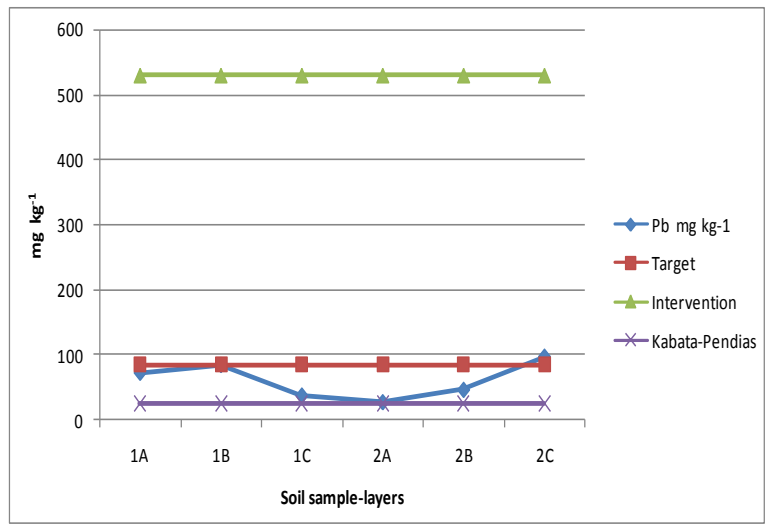

d)

Figure 3 - Concentrations of $\mathrm{Cu}(a), A s(b), \mathrm{Zn}(\mathrm{c})$ and $\mathrm{Pb}(\mathrm{d})$ in comparison with relevant reference values

Pollution load index (PLI) proposed by [20], [21] is an empirical index that comparatively assesses the level of heavy metal pollution for each sampling site. PLI was calculated by the relation:

$$
P L I=\left(C_{f 1} x C_{f 2} x C_{f 3} x \ldots . x C_{f n}\right)^{1 / n}
$$

where: $n-$ number of assessed metals ( $n=8$ herein)

$\mathrm{Cf}$ - contamination factor of individual pollutant

The value of PLI was classified into four groups [11]:

\begin{tabular}{|l|l|l|}
\hline group & pollution & PLI \\
\hline (i) & no & $<1$ \\
\hline (ii) & moderate & $1-2$ \\
\hline (iii) & heavy & $2-3$ \\
\hline (iv) & extreme & $\geq 3$ \\
\hline
\end{tabular}

As can be seen from Table 2 above, pollution load index (PLI), ranged from 1.840 to 3.394 , suggesting moderate to extreme pollution according to previously mentioned classification [11], although the majority of PLI values were in the heavy pollution class.

Mining and smelting activities in the study area were focused predominantly on copper production, therefore contamination with this metal has for long term been considered the most serious [12], [13], [14], [15], [16].

The concentrations of copper and the other 7 heavy metals are highest in layers $C$ (footwall) because the concentration of those metals while in solution was highest because the largest were the extracts from the primarily deposited mineralized rocks (waste dump) in the Buchim mine in which vicinity is located Buchim Lake (Figure 1). 
Table 2. Values of contamination factor $\left(C_{f}\right)$ and degree of contamination $\left(C_{d}\right)$ for each sampled level in both evaluated sections/profiles (1 and 2) as well as pollution load index (PLI)

\begin{tabular}{|c|c|c|c|c|c|c|c|c|c|c|}
\hline \multirow[b]{2}{*}{ Sampl. } & \multicolumn{8}{|c|}{ Contamination factor $\left(C_{f}\right)$} & \multirow{2}{*}{$\begin{array}{l}\mathrm{C}_{\mathrm{d}} \text { (degre of } \\
\text { contamination) }\end{array}$} & \multirow[b]{2}{*}{ PLI } \\
\hline & As & Co & $\mathrm{Cr}$ & $\mathrm{Cu}$ & $\mathrm{Ni}$ & $\mathrm{Pb}$ & $\mathrm{V}$ & $\mathrm{Zn}$ & & \\
\hline $1 \mathrm{~A}$ & 0.517 & 3.861 & 0.746 & 74.841 & 1.702 & 0.843 & 2.102 & 1.053 & 85.665 & 2.083 \\
\hline $1 \mathrm{~B}$ & 1.217 & 1.222 & 0.617 & 162.044 & 1.765 & 0.983 & 1.597 & 0.944 & 170.389 & 2.107 \\
\hline $1 \mathrm{C}$ & 1.181 & 3.440 & 0.606 & 106.014 & 3.028 & 0.437 & 1.790 & 1.683 & 118.179 & 2.383 \\
\hline 1 aver. & 0.972 & 2.841 & 0.656 & 114.300 & 2.165 & 0.754 & 1.830 & 1.227 & 124.745 & 2.291 \\
\hline $2 \mathrm{~A}$ & 0.756 & 6.333 & 0.293 & 77.159 & 2.382 & 0.318 & 0.820 & 1.947 & 90.009 & 1.840 \\
\hline $2 \mathrm{~B}$ & 1.788 & 2.674 & 0.685 & 90.781 & 1.927 & 0.539 & 1.935 & 1.231 & 101.560 & 2.282 \\
\hline $2 \mathrm{C}$ & 2.073 & 4.937 & 0.758 & 187.480 & 2.721 & 1.130 & 2.204 & 1.785 & 203.088 & 3.394 \\
\hline 2 aver. & 1.539 & 4.648 & 0.579 & 118.473 & 2.343 & 0.662 & 1.653 & 1.654 & 131.552 & 2.599 \\
\hline
\end{tabular}

The results of the waters (source Bucim Mine laboratory) in those first leached solutions reached up to $480 \mathrm{mg} \mathrm{l}^{-1} \mathrm{Cu}$, while much later when the material was repeatedly leached the copper content dropped to $100 \mathrm{mg} \mathrm{l}^{-1} \mathrm{Cu}$ in the water solutions. This indicates that the precipitation of heavy metals and their deposition in mud soil is directly proportional to the amount of dissolved metals in the water over a period of time. This is confirmed by the fact that our experiment, where in layers A of mud soil samples which are the most recently exposed, copper content and other treated heavy metals, is significantly lower. These findings are quite in line with findings of some other researchers for similar worldwide localities [22], [23], [24].

\section{CONCLUSION}

The imediate area of the Buchim lake around active Buchim Mine, showed increased concentrations of As $(14.985 \div 60.131 \mathrm{mg} \mathrm{kg}-1), \mathrm{Cu}(2694 \div 6749 \mathrm{mg} \mathrm{kg}$ $1)$, $\mathrm{Pb}(27.06 \div 96.08 \mathrm{mg} \mathrm{kg}-1)$ and $\mathrm{Zn}(147 \div 273 \mathrm{mg}$ $\mathrm{kg}-1)$ in analyzed soil mud from the botom of the lake. Computed contamination factor $\left(C_{f}^{i}\right)$ indicated low to very high values (especially for $\mathrm{Cu}$ ), degree of contamination (Cd) showed very high degree of contamination while the pollution load index (PLI) indicated heavy to extreme pollution.

\section{REFERENCES}

[1] Kabata-Pendias A, and Pendias, H., Trace elements in soils and plants. CRC Press, Boca Raton, FL ( $3^{\text {rd }}$ edition), pp. 413, 2001.

[2] Li J, Xie Z. M, Zhu Y. G. and Naidu, R, Risk assessment of heavy metal contaminated soil in the vicinity of a lead/zinc mine. J Environ Sci China 17:881-885, 2005.

[3] Li Y, Wang Y. B, Gou X, Su Y. and Wang, G, Risk assessment of heavy metals in soils and vegetables around non-ferrous metals mining and smelting sites, Baiyin, China. J Environ Sci China 18:1124-1134, 2006.

[4] Wilson B, Lang B. and Pyatt F. B, The dispersion of heavy metals in the vicinity of Britannia Mine, British Columbia, Canada. Ecotoxicol Environ Saf 60:269-276, 2005.

[5] Pruvot C, Douay F, Herve F. and Waterlot C, Heavy metals in soil, crops and grass as a source of human exposure in the former mining areas. J Soils Sediment 6:215-220, 2006.

[6] Ma L, Sun, J, Yang Z. and Wang L, Heavy metal contamination of agricultural soils affected by mining activities around the Gabxi River in Chenzhou Southern China. Environmental Monitoring and Assessment, 187: 731-740, 2015.

[7] Li Z. Y, Ma Z. W, van der Kuijp, T. J, Yuan Z. W. and Huang $\mathrm{L}$, A review of soil heavy metal pollution from mines in China: pollution and health risk assessment. Science of the Total Environment, 468: 843853. 2014.

[8] Iavazzo P, Adamo P, Boni M, Hillier S. and Zampella $\mathrm{M}$, Mineralogy and chemical forms of lead and zinc in abandoned mine wastes and soils: an example from Morocco. Journal of Geochemical Exploration, 113: 56-67, 2012.

[9] Violante A, Huang M. P. and Gadd M. G, Biophysico-chemical processes of heavy metals and metaloids in soil environments. New Jersey, John Wiley \& Sons, - pp. 659, 2008

[10]Demková L, Jezný T. and Bobul'ská, L, Assessment of Soil Heavy Metal Pollution in a Former Mining Area-Before and After the End of Mining Activities. Soil and Water Research 12 (4), pp. 229-236, 2016.

[11]Lizárraga-Mendiola L, González-Sandoval, M. R, Durán-Domínguez M. C, Márquez-Herrera C, Geochemical behaviour of heavy metals in a $\mathrm{Zn}-\mathrm{Pb}-\mathrm{Cu}$ 
mining area in the State of Mexico (central Mexico). Environmental Monitoring and Assessment, 155: 355-372, 2009.

[12]Balabanova B, Stafilov T, Bačeva K, Šajn R, Atmospheric pollution with copper around the copper mine and flotation, Bučim, Republic of Macedonia, using biomonitoring moss and lichen technique, Geologica Macedonica, 23, 35-41, 2009.

[13]Stafilov T, Balabanova B, Šajn R, Bačeva K. and Boev B, Geochemical atlas of Radoviš and the environs and the distribution of heavy metals in the air, Faculty of Natural Sciences and Mathematics, Skopje 2010

[14]Serafimovski, T, Nikolov, N, Konzulov G, Tasev G. and Sarafiloski S, Water monitoring around the Buchim copper mine drainage system. 13th International Multidisciplinary Scientific Geoconference SGEM 2013, 1. pp. 1211-1218. ISSN 1314-2704, 2013.

[15]Serafimovski T, Nikolov N, Konzulov G, Tasev G. and Sarafiloski S, Influence of the Buchim copper leaching factory on the environ around the active Buchim copper mine. International Multidisciplinary Scientific GeoConference (SGEM 14), I (1). pp. 383390. ISSN 1314-2704, 2014.

[16]Serafimovski T, Konzulov G, Tasev G, Stefanova V. and Sarafiloski S, Soil contamination study around the Buchim Copper Mine, Republic of Macedonia. The Journal of Ege University Faculty of Agriculture, Spec. iss., pp. 55-62. ISSN 1018-8851, 2015.

[17]Balabanova B, Stafilov T, Baceva K. and Vuckovic I, Heavy metals toxicity and bioaccumulation in vegetables from potentially polluted area. Scientific Works. pp. 615-620. ISSN 1314-7102, 2013.

[18]Dutch Target and Intervention Values, (the New Dutch List). Esdat Environmental Database Management Software, www.esdat.net, 51 p., 2000.

[19]Kabata-Pendias A, Trace Elements in Soils and Plants. London, Taylor and Francis Group, 2011.

[20]Hakanson L, An ecological risk index for aquatic pollution control. A sedimentological approach. Water Research, 14: 975-1001, 1980.

[21]Tomlinson D. L, Wilson J. G, Harris C. R, Jeffrey D. $\mathrm{W}$, Problems in the assessment of heavy-metal levels in estuaries and the formation of a pollution index. Helgoländer Meeresuntersuchungen, 33: 566-575, 1980

[22]Christou A, Theologides C. P, Costa C, Kalavrouziotis I. K. and Varnavas S. P, Assessment of toxic heavy metals concentrations in soils and wild and cultivated plant species in Limni abandoned cooper mining site, Cyprus. J. Geochem. Explor., 178, 16-22, 2017.

[23]Liu B, Ai S, Zhang W, Hunang D. and Zhang Y, Assessment of the bioavailability, bioaccessibility and transfer of heavy metals in the soil-grain-human systems near a mining and smelting area in NW China. Sci. Total Environ., 609, 822-829, 2017.

[24]Cheng X, Drozdova J, Danek T, Huang Q, Qi W, Yang S, Zou L, Xiang Y. and Zhao X, Pollution Assessment of Trace Elements in Agricultural Soils around Copper Mining Area. MDPI-Sustainability, 10, 4533 (1-18), 2018. 


\section{REZIME}

\section{SADRŽAJ BAKRA I PRATEĆIH ELEMENATA I VIŠESLOJNOM BLATNJAVOM ZEMLJIŠTU IZ BUČIMSKOG JEZERA ISPOD JALOVIŠTA RUDNIKA „BUČIM“, REPUBLIKA SEVERNA MAKEDONIJA}

Intenzivna eksploatacija minerala u rudarskim područjima tokom poslednjih nekoliko decenija producirala je $i$ velike količine otpadnog materijala $i$ jalovine, koji oslobađaju toksične elemente $i$ životnu sredinu. Cilj ovoj proučavanja je bio da se u dva vertikalna profila/preseka (1 i 2 ) utvrde sadržaji teških metala u uzorcima dobijenih iz šest uzorarka, po tri iz svakog profila koji se nalaze na području rudnika porfirskog bakra Bučim, Republika Severna Makedonija. Rezultati su upoređeni sa standardima nove holandske liste (DL) i standardima Kabata-Pendias (KP) i zaključeno je sledeće: vrednosti As su

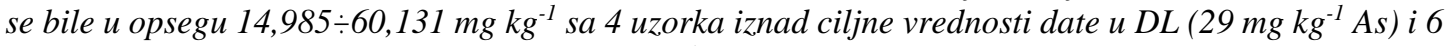
iznad standardnih vrednosti datih u KP $\left(5 \mathrm{mg} \mathrm{kg}^{-1} \mathrm{As}\right)$, u tom kontekstu vrednosti Co su bile u opsegu 11 $\div 57 \mathrm{mg} \mathrm{kg}^{-1}$ sa 6 vrednosti iznad ciljne vrednosti date u $D L\left(9 \mathrm{mg} \mathrm{kg}^{-1} \mathrm{Co}\right)$ i 5 iznad standardnih vrednosti datih u KP (12 $\left.\mathrm{mg} \mathrm{kg}^{-1} \mathrm{Co}\right)$, Cr u opsegu 29,32 $\div 75,76 \mathrm{mg} \mathrm{kg}^{-1}$ sa 6 vrednosti iznad KP vrednosti (10 mg

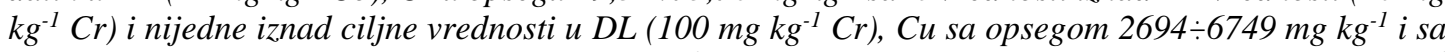
6 uzoraka iznad ciljne vrednosti u DL $\left(36 \mathrm{mg} \mathrm{kg}^{-1} \mathrm{Cu}\right)$ i 6 iznad standardne vrednosti u KP (20 $\mathrm{mg} \mathrm{kg}^{-1}$

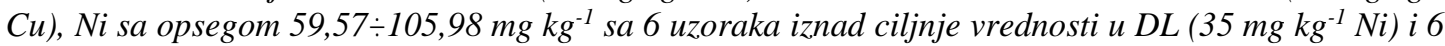
iznad standardnih vrednosti u datih u KP (20 mg kg-1 $\mathrm{Ni}), \mathrm{Pb}$ sa opsegom 27,06 $\div 96,08 \mathrm{mg} \mathrm{kg}^{-1}$ i 1 uzorkom iznad ciljne vrednosti u DL $\left(85 \mathrm{mg} \mathrm{kg}^{-1} \mathrm{~Pb}\right)$ i 6 iznad standardnih vrednosti datim u KP (25 $\mathrm{mg}$ $\left.\mathrm{kg}^{-1} \mathrm{~Pb}\right), \mathrm{Zn}$ sa opsegom $147 \div 273 \mathrm{mg} \mathrm{kg}^{-1}$ sa 6 vrednostima iznad ciljne vrednosti date u DL (140 $\mathrm{mg} \mathrm{kg}^{-}$ $\left.{ }^{I} \mathrm{Zn}\right)$ i 6 iznad standardne KP vrednosti (64 $\mathrm{mg} \mathrm{kg}^{-1} \mathrm{Zn}$ ), V sa opsegom 34,44 $\div 92,57 \mathrm{mg} \mathrm{kg}^{-1}$ i 5 vrednosti iznad ciljne vrednosti u DL (42 $\left.\mathrm{mg} \mathrm{kg}^{-1} \mathrm{~V}\right)$ i jedne iznad KP vrednosti $\left(90 \mathrm{mg} \mathrm{kg}^{-1} \mathrm{~V}\right.$ ). Da bi se uporedio nivo kontaminacije, izračunati su faktor kontaminacije $\left(C_{f}^{i}\right)$, stepen kontaminacije $\left(C_{d}\right)$, i indeks zagađenja (PLI). Ozbiljne vrednosti su pronađene za Cu, As, Zn, Co i Ni, koje su prevazišle standardne vrednosti skoro u svim uzorcima iz oba vertikalna profila/preseka. U poređenju profil 1 sa profilom 2, indeks zagađenja je povećan za 13,43\%, što je skoro u svim uzorcima klasifikovano kao visoko zagađeno do izuzetno zagađeno. Činjenica je da rudarske aktivnosti rudnika Bučim traju gotovo 40 godina, pa je razumljivo prisustvo teških metala u ozbiljnim nivoima. Visok nivo kontaminacije rezultat je istrajnosti teških metala i bio-nerazgradljivosti.

Ključne reči: zemljište, zagađenje, bakar, porfirski, Bučim 